\title{
NOTE
}

\section{A COMPARISON OF THE EFFICACY OF ANTHELMINTHIC DRUGS IN THE TREATMENT OF HOOK-WORM INFECTION}

Tetrachlorethylene has been used with success for a long time in the treatment of hook-worm infection. In 1958 Goodwin et al. made clinical trials with bephenium hydroxynaphthoate on a group of patients in Ceylon and claimed that it was better than tetrachlorethylene by higher in efficacy and less in toxicity. Since then there were many reports mentioning the satisfactory results of bephenium (Nazaly et al., 1959; Ahmid et al., 1957 ; Hahn et al., 1960 ; Hsieh et al., 1960 ; Jung et al., 1960 ; Young et al., 1960). Recently in Japan a new drug known as bromo-naphthol $\dagger$ was reported to be a superior grade anthelminthic (Yoshida et al., 1961, personal communication). The authors were very much interested in these drugs especially in the last one, and had an opportunity to try them on the labourers and their families of Na-Bon Rubber Plantation in Nakorn-Sritharmaraj Province, South Thailand. This report revealed the successful results.

\section{Materials \& Methods.}

1. The infected persons: 212 infected persons were included in this series. Their faeces showed a moderate amount of hook-worm ova, quite easily seen by a simple smear method. They were 152 males and 60 females and their ages ranged between 21 and 40 years.

After the anthelminthics, the hook-worms were collected and examined for the species and it was found that $88.9 \%$ of cases had Necator aamericanus, $3.2 \%$ had Ancylostoma duodenale and $7.9 \%$ had both of them.

2. The drugs: Tetrachlorethylene was administered in the form of gelatin capsules. Each capsule contained $1 \mathrm{cc}$ of the drug. The dosage was 4 capsules per one person. The drug was administered early in the morning after the infected person was prepared one day previously.* The saline purgative was given two hours after the anthelminthic.

Bephenium hydroxynaphthoate** granules were mixed with cold water and administered to the infected person 4 hours after lunch time. The dosages were $2.5 \mathrm{~g}$ either one day or 2 consecutive days.

Bromo-naphthol*** granules were suspended in cold water before use. The dosages were either $6 \mathrm{~g}$ or $9 \mathrm{~g}$ for an individual.

3. The interpretation of the result: The intensity of the infection in each individual was determined by "Stoll Egg Count". There were 94 cases who had 500-999 ova in one gram faeces, 102 cases had 1,000-4,999 ova, and 16 cases had 5,000 or over ova.

On the 2nd week after administration of the drugs, the faeces of the treated persons were again collected and examined by the floatation method. They were "cured" when the results were negative. In cases showing ova of the parasite, "Stoll Egg Count" was again done in

† Bromo-naphthol is a chemical product with fine crystals, slightly bitter taste and is slightly soluble in water.

* The infected person was advised not to have much fatty food and not to drink alcoholic beverage. He had soft diet in the evening.

** Bephenium was supplied as "Alcopar"

*** Bromo-naphthol used in this investigation was supplied by Toyama Chemical Industrial Co. Ltd. as "Wormin". 
order to determine the intensity of the infection. It was regarded as "improved" when the number of the ova per one gram faeces was less than $50 \%$ of the original, and as "not improved" when it was equal to or more than $50 \%$.

4. The side effects: The side effects of the drugs in each individual were observed carefully, especially within 48 hours after administration of the drugs.

5. The other intestinal helminthes: The action of Bephenium and Bromo-naphthol on ascariasis and trichuriasis (with hook worm infection) was also observed in some cases. Their ova in the faeces were noted by "Stoll Egg Count" before and again one week after administration of the drugs. The interpretation of the results was in the same way as that in the hook worm infection.

\section{Results.}

Of all 212 persons, 30 were treated with tetrachlorethylene, 93 with bephenium hydroxynaphthoate, and 89 with bromo-naphthol. The results are shown in Table 1.

The side effects occurred usually within 48 hours after the drugs, and they are shown in Table 2.

29 ascariasis and 25 trichuriasis with hook worm infection cases were observed for the action of Bephenium and bromo-naphthol. The details of the results are shown in Table 3 and Table 4.

Table 1. The results of the treatment of the hook worm infection with tetrachlorethylene, bephenium hydroxynaphthoate and bromo-naphthol

\begin{tabular}{|c|c|c|c|c|c|c|c|c|c|}
\hline \multirow{2}{*}{ Drugs } & \multirow{2}{*}{ Dosage } & \multirow{2}{*}{$\begin{array}{l}\text { No. of } \\
\text { persons } \\
\text { treated }\end{array}$} & \multicolumn{2}{|c|}{ Cured } & \multicolumn{2}{|c|}{ Improved } & \multirow{2}{*}{$\begin{array}{c}\% \\
\text { cured } \\
+ \\
\text { improved } \\
\end{array}$} & \multicolumn{2}{|c|}{$\begin{array}{c}\text { Not } \\
\text { improved }\end{array}$} \\
\hline & & & No. & $\%$ & No. & $\%$ & & No. & $\%$ \\
\hline Tetrachlorethylene & $4 \mathrm{cc}$ & 30 & 16 & 53.3 & 11 & 36.7 & 90.0 & 3 & 10.0 \\
\hline \multirow{3}{*}{$\begin{array}{l}\text { Bephenium } \\
\text { hydroxynapho- } \\
\text { thlate }\end{array}$} & $\begin{array}{l}2.5 \mathrm{~g} \\
\text { one day }\end{array}$ & 47 & 12 & 25.5 & 21 & 44.7 & 70.2 & 14 & 29.8 \\
\hline & $\begin{array}{l}2.5 \mathrm{~g} \\
\text { two days }\end{array}$ & 46 & 19 & 41.3 & 14 & 30.4 & 71.7 & 13 & 28.3 \\
\hline & Total & 93 & 31 & 33.3 & 35 & 37.6 & 70.9 & 27 & 29.1 \\
\hline \multirow{3}{*}{ Bromo-naphthol } & $6 \mathrm{~g}$ & 42 & 14 & 33.3 & 21 & 50.0 & 83.3 & 7 & 16.7 \\
\hline & $9 \mathrm{~g}$ & 47 & 32 & 68.1 & 12 & 25.5 & 93.6 & 3 & 6.4 \\
\hline & Total & 89 & 46 & 51.7 & 33 & 37.1 & 88.8 & 10 & 11.2 \\
\hline Grand total & - & 212 & 93 & 43.9 & 79 & 37.3 & 81.2 & 40 & 18.8 \\
\hline
\end{tabular}

\section{Discussion.}

The results of the treatment of hook-worm infection with three anthelminthics in this series were slightly different from each other. Bromo-naphthol in the dose of $9 \mathrm{~g}$ gave the best result, $68.1 \%$ as "cured". $4 \mathrm{cc}$ of tetrachlorethylene and $6 \mathrm{~g}$ and $9 \mathrm{~g}$ of Bromo-naphthol showed very high efficiency, $90.0 \%, 83.3 \%$ and $93.6 \%$ respectively as "cured" and "improved", however, the former drug gave more side effects than the latter. Dizziness, nausea and abdominal trouble were the main symptoms of tetrachlorethylene administration.

Bephenium in two doses of $2.5 \mathrm{~g}$ each gave better "cured" result than that of one single dose ( $41.3 \%$ vs. $25.5 \%$ ), and even though there were many side effects such as nausea, vomiting, lassitude and diarrhea, they were very mild.

However, by interpreting the results in egg reduction rate (the difference between 
Table 2. The side effects in 30 cases of tetrachlorethylene treatment, 93 cases of bephenium and 89 cases bromo-naphthol

\begin{tabular}{|c|c|c|c|c|c|c|c|}
\hline \multirow[b]{2}{*}{ No. } & \multirow[b]{2}{*}{ Symptoms } & \multicolumn{2}{|c|}{ Tetrachlorethylene } & \multicolumn{2}{|c|}{ Bephenium } & \multicolumn{2}{|c|}{ Bromo-naphthol } \\
\hline & & $\begin{array}{l}\text { No. of } \\
\text { persons } \\
\text { affected }\end{array}$ & $\%$ & $\begin{array}{l}\text { No. of } \\
\text { persons } \\
\text { affected }\end{array}$ & $\%$ & $\begin{array}{l}\text { No. of } \\
\text { persons } \\
\text { affected }\end{array}$ & $\%$ \\
\hline 1 & Abdominal discomfort & 6 & 20.0 & 13 & 14.0 & 10 & 11.2 \\
\hline 2 & Abdominal pain & 5 & 16.7 & 8 & 8.6 & 5 & 5.6 \\
\hline 3 & Bloody mucous stoll & - & - & 7 & 7.5 & - & - \\
\hline 4 & Diarrhea, mild & 6 & 20.0 & 21 & 22.6 & 10 & 11.2 \\
\hline 5 & Diarrhea, severe & - & - & 2 & 2.2 & 1 & 1.1 \\
\hline 6 & Dizziness & 17 & 56.7 & - & - & $\begin{array}{c}20 \\
\text { (very mild) }\end{array}$ & 22.5 \\
\hline 7 & Lassitude, mild & - & - & 52 & 55.9 & - & - \\
\hline 8 & Lassitude, severe & - & - & 2 & 2.2 & - & - \\
\hline 9 & Fainting & - & - & 1 & 1.0 & - & - \\
\hline 10 & Fever & - & - & 1 & 1.0 & - & - \\
\hline 11 & Headache & 2 & 6.7 & 5 & 4.3 & 1 & 1.1 \\
\hline 12 & Nausea & 12 & 40.0 & 56 & 60.2 & 24 & 27.0 \\
\hline 13 & Numbness & 12 & 40.0 & 1 & 1.0 & - & - \\
\hline 14 & Vertigo & 7 & 23.3 & - & - & - & - \\
\hline 15 & Vomiting, mild & 10 & 33.3 & 37 & 39.8 & 13 & 14.6 \\
\hline 16 & Vomiting, severe & - & - & 4 & 4.3 & - & - \\
\hline
\end{tabular}

Table 3. The results of administration of bephenium and bromo-naphthol to 29 ascariasis cases* (with hook worm infection)

\begin{tabular}{|c|c|c|c|c|c|c|c|c|}
\hline \multirow{2}{*}{ Drugs } & \multirow{2}{*}{ Dosage } & \multirow{2}{*}{$\begin{array}{l}\text { No. persons } \\
\text { observed }\end{array}$} & \multicolumn{2}{|c|}{ Cured } & \multicolumn{2}{|c|}{ Improved } & \multicolumn{2}{|c|}{ Not improved } \\
\hline & & & No. & $\%$ & No. & $\%$ & No. & $\%$ \\
\hline \multirow{3}{*}{ Bephenium } & $\begin{array}{l}2.5 \mathrm{~g} \\
\text { one day }\end{array}$ & 8 & 7 & 87.5 & 1 & 12.5 & - & - \\
\hline & $\begin{array}{l}2.5 \mathrm{~g} \\
\text { two days }\end{array}$ & 7 & 7 & 100.0 & - & - & - & - \\
\hline & Total & 15 & 14 & 93.3 & 1 & 6.7 & - & - \\
\hline \multirow{3}{*}{ Bromo-naphthol } & $6 \mathrm{~g}$ & 6 & 3 & 50.0 & 3 & 50.0 & - & - \\
\hline & $9 \mathrm{~g}$ & 8 & 5 & 62.5 & 2 & 25.0 & 1 & 12.5 \\
\hline & Total & 14 & 8 & 57.1 & 5 & 35.7 & 1 & 7.2 \\
\hline Grand total & - & 29 & 22 & 75.8 & 6 & 20.7 & 1 & 3.5 \\
\hline
\end{tabular}

* Ascaris ova in each case were between 400 and 30,800 per $\mathrm{g}$ faeces.

the numbers of "Stoll count" eggs obtained from each group of cases before and after the treatment) it was found that $9 \mathrm{~g}$ of bromo-naphthol gave the highest rate of $93.4 \%$. The results are shown in Table 5 .

The anthelminthic actions to ascariasis and trichuriasis with hook-worm infection were also noted. In ascariasis, bephenium was superior over bromo-naphthol $(93.3 \%$ 
Table 4. The results of administration of bephenium and bromonapthol to 25 trichuriasis cases* (with hook worm infection)

\begin{tabular}{|c|c|c|c|c|c|c|c|c|}
\hline \multirow{2}{*}{ Drugs } & \multirow{2}{*}{ Dosage } & \multirow{2}{*}{$\begin{array}{c}\text { No. person } \\
\text { observed }\end{array}$} & \multicolumn{2}{|c|}{ Cured } & \multicolumn{2}{|c|}{ Improved } & \multicolumn{2}{|c|}{ Not improved } \\
\hline & & & No. & $\%$ & No. & $\%$ & No. & $\%$ \\
\hline \multirow{3}{*}{ Bephenium } & $\begin{array}{l}2.5 \mathrm{~g} \\
\text { one day }\end{array}$ & 7 & 4 & 57.1 & 1 & 14.3 & 2 & 28.6 \\
\hline & $\begin{array}{l}2.5 \mathrm{~g} \\
\text { two days }\end{array}$ & 4 & 1 & 25.0 & 1 & 25.0 & 2 & 50.0 \\
\hline & Total & 11 & 5 & 45.4 & 2 & 18.2 & 4 & 36.4 \\
\hline \multirow{3}{*}{ Bromo-naphthol } & $6 \mathrm{~g}$ & 6 & 5 & 83.3 & 1 & 17.7 & - & - \\
\hline & $9 \mathrm{~g}$ & 8 & 4 & 50.0 & 2 & 25.0 & 2 & 25.0 \\
\hline & Total & 14 & 9 & 64.3 & 3 & 21.4 & 2 & 14.3 \\
\hline Grand total & & 25 & 14 & 56.0 & 5 & 20.0 & 6 & 24.0 \\
\hline
\end{tabular}

* Trichuris ova in each case were between 400 and 20,000 per $\mathrm{g}$ faeces.

vs. $57.1 \%$ cure rate) but in trichuriasis the latter drug gave better result $(64.3 \%$ cure rate) than the former $(45.4 \%$ cure rate).

\section{Conclusions.}

Tetrachlorethylene, Bephenium hydroxynaphthoate and Bromo-naphthol were tried in 212 cases of hook worm infection in the labourers and their families of $\mathrm{Na}$-Bon Rubber Plantation in Nakorn-Sritharmaraj, South Thailand. All three showed satisfactory results. However, Bromo-naphthol in the dose of $9 \mathrm{~g}$ gave the best result, both in high percentage of cure rate $(68.1 \%)$ and least toxicity.

The effects of Bephenium and Bromo-naphthol on ascariasis and trichuriasis with hook-worm infection were also noted with moderate results. However, Bephenium seemed to be a very valuable drug in the treatment of ascaris infection.

Table 5. The results of the treatment of the hook-worm infection with tetrachlorethylene, bephenium hydroxynaphthoate and bromonaphthol as interpreted in the egg reduction rate

\begin{tabular}{|c|c|c|c|c|c|}
\hline \multirow{2}{*}{ Drugs } & \multirow{2}{*}{ Dosage } & \multirow{2}{*}{$\begin{array}{l}\text { No. of } \\
\text { cases }\end{array}$} & \multicolumn{3}{|c|}{ Total Stoll Egg Count per $\mathrm{g}$ of faeces } \\
\hline & & & $\begin{array}{c}\text { Before } \\
\text { treatment }\end{array}$ & $\begin{array}{c}\text { After } \\
\text { treatment }\end{array}$ & $\begin{array}{l}\text { Egg reduction } \\
\text { rate }\end{array}$ \\
\hline Tetrachlorethylene & $4 \mathrm{cc}$ & 30 & 44,100 & 6,400 & 83.4 \\
\hline & $2.5 \mathrm{~g}$ & 47 & 82,600 & 13,800 & 83.3 \\
\hline Bephenium & $\begin{array}{l}2.5 \mathrm{~g} \\
2 \text { days }\end{array}$ & 46 & 68,800 & 9,600 & 86.0 \\
\hline Total & - & 93 & 151,400 & 23,400 & 84.5 \\
\hline Bromo-nanhthol & $6 \mathrm{~g}$ & 42 & 122,200 & 10,600 & 91.3 \\
\hline Diono-irapintiol & $9 \mathrm{~g}$ & 47 & 94,800 & 6,200 & 93.4 \\
\hline Total & - & 89 & 217,000 & 16,800 & 92.3 \\
\hline Grand total & - & 212 & 413,000 & 46,600 & 88.7 \\
\hline
\end{tabular}


The authors wish to thank Mr. Choob Muniganond, the Director of the Na-Bon Rubber Plantation for his kind help and co-operation; Toyama Chemical Industrial Co. Ltd. for their supply of Bromo-naphthol ("Wormin"), and the technicians of the Faculty of Tropical Medicine, University of Medical Sciences for their valuable help.

\section{REFERENCES}

Ahmid, N. \& RASOOL, G. (1959) : Bephenium hydroxynaphthoate against hookworm in West Pakistan. J. Trop. Med. \& Hyg., 62, 255.

BOokLET on "Wormin" (1 Bromo B Naphthol) of Toyama Chemical Industrial Co. Ltd.

Goodwin, L. G., Jayewardene, L. G. \& Standen, B. D. (1958) : Clinical trials with bephenium hydroxynaphthoate against hookworm in Ceylon. Brit. M. J., 2, 1572.

HAHN, S. S., KAHN, H. Y. \& HAHN, Y.S. (1960): The anhelminthic effect of bephenium hydroxynaphthoate on intestinal helminths. J. Trop. Med. \& Hyg., 63, 180.

Hsieh, H. C., Brown, H. W., Fite, M., Chow, L. P., Cheng, C. S. \& Hsu, C. C. (1960) : The treatment of hookworm, ascaris and trichuris infections with bephenium hydroxynaphthoate. Am. J. Trop. Med. \& Hyg., 9, 496.

JUNG, R. C. \& MC. CROAN, J. E. (1960): Efficacy of bephenium and tetrachlorethylene in mass treatment of hookworm infection. Am. J. Trop. Med. \& Hyg., 9, 492.

NAGATY, H. F. \& RifAAT, M. A. (1959): Clinical trials with bephenium hydroxynaphthoate against Ancylostoma duodenale and other helminthic infections. J. Trop. Med. \& Hyg., $62,284$.

Yoshida, Y., NAKanishi, Y., Shimatani, T. \& Matuo, K. (1961) : Comparative studies on the anhelminthic effect of bephenium hydroxynaphthoate, tetrachlorethylene, 1-bromo B naphothol and 4-iodothymol against the human hookworm : Personal communication.

Young, M. D., Jefferey, G. M., Morehouse, W. G., Freed, J. E. \& Johnson, R. S. (1960) : The comparative efficacy of bephenium hydroxynaphthoate against hookworm and other parasites of man. Am. J. Trop. Med. \& Hyg., 9, 488.

Bangkok School of Tropical Medicine and Endemic Diseases, Faculty of Tropical Medicine, University of Medical Sciences, Thailand
PiPAT JUTTIJUDATA PENSRI GUPTAVANIJ CHAMLONG HARINASUTA

Received: November 27th, 1961. 